\title{
The Fortress of Ripafratta, Tuscany. A research project for its conservation and enhancement
}

\author{
Marco Giorgio Bevilacqua $^{\text {a }}$, Ewa Jolanta Karwaca ${ }^{\text {b }}$, Valeria Mininno ${ }^{\text {, }}$, Michele Angelo \\ Perrone $^{d}$, Luisa Santini ${ }^{\text {e }}$ \\ University of Pisa, Pisa, Italy \\ a mg.bevilacqua@ing.unipi.it; b e.karwacka@ing.unipi.it; ${ }^{\mathrm{c}}$ valeria.mininno@unipi.it; ${ }^{\mathrm{d}}$ mikangelo.perrone@ gmail.com; \\ eluisa.santini@unipi.it
}

\begin{abstract}
The fortress of San Paolino in Ripafratta (San Giuliano Terme, Tuscany, Italy), represents the main structure of the ancient Pisan Republic defensive system towards Lucca. The fortress is the product of several stratifications dating back to the tenth century. It was built in the years between 1162-1164; later on, starting from 1504, significant interventions of modernization were realized by the Florentine Government, probably following a project by Giuliano da San Gallo. Since the early seventeenth century, the fortress lost its military function and passed to private property. Nowadays, the fortress is in a deep state of degradation, even if since 2008 several initiatives has followed for its recovery, unfortunately without success. The paper aims to show the results of an interdisciplinary project for the enhancement of the fortress and its territory. Based on a careful territorial analysis and in-depth historical study, a mix of compatible functions was identified in order to maximize the use of the fortress in all the seasons. A feasibility study was also developed for verifying the economic sustainability of the whole project and identifying possible intervention phases.
\end{abstract}

Keywords: Ripafratta, fortress, enhancement, conservation.

\section{Introduction}

The fortress of San Paolino in Ripafratta, located on the Vergario hill, in the territory of San Giuliano Terme (Pisa, Tuscany), along the Serchio river (Fig. 1), represents the most important stronghold of the Pisan Republic defensive system towards Lucca in the Middle Age, composed also by some towers, such as the near Niccolai and Centino towers, the bell tower of the current church of Ripafratta and two other towers -the Mucchietto tower and an anonymous one- of which only a few remains are preserved. The fortress is the product of several stratifications dating back to the tenth century.
Since the early seventeenth century, the fortress lost its military function and passed to private property. Nowadays, the fortress is in a deep state of degradation, even since 2008 several initiatives has followed for its recovery, unfortunately without success.

In 2015, a new initiative for the recovery of the fortress was promoted by the municipal administration of San Giuliano Terme and the Salviamo La Rocca APS Association with the involvement of the Pisa Foundation. The initiative stalled substantially for economic and financial reasons, due primarily to the impossibility of the 


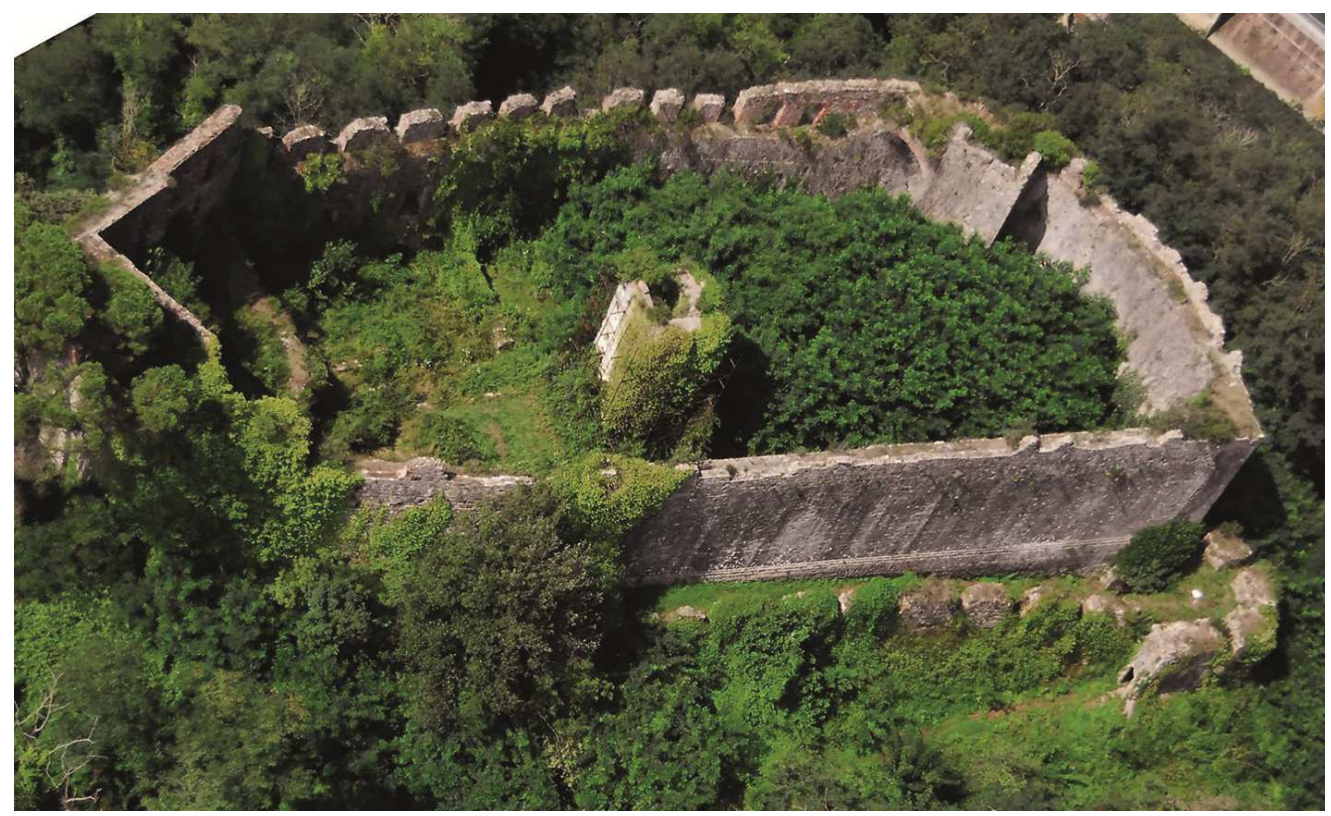

Fig. 1. View of the Vergario hill with the fortress of San Paolino (courtesy of Salviamo La Rocca APS).

Municipality of San Giuliano to cover at that time the costs of acquisition of the fortress and its ordinary management, as highlighted by a feasibility study commissioned by the same Pisa Foundation to ASK Bocconi.

In September 2017, an agreement was signed between the Municipality of San Giuliano Terme, the Department of Energy, Systems, Territory and Construction Engineering (DESTeC) of the University of Pisa and the Association, aimed at developing a new detailed study for the recovery and management of the fortress.

In order to attract as much as possible interest about the necessity of intervening for the conservation and enhancement of the fortress, in May 2018 the Association promoted the candidacy of the fortress as a F.A.I. (Fondo Ambiente Italiano) "Luogo del Cuore", candidacy supported also by the Municipal Council of San Giuliano Terme; this allowed the involvement of the Regional Administration of Tuscany and the Italian Ministry for Cultural Heritage and Activities and for Tourism (MiBACT) in the recovery process, thus bringing the issue of the Rocca outside the local area for the first time.
Following the first agreement of 2017, in May 2019, a Promoting Committee was formally constituted by representatives of the University of Pisa, the Municipality of San Giuliano Terme and the Salviamo La Rocca APS Association, with the specific task of promoting the development and implementation of the enhancement project. At the same time, the Municipality of San Giuliano started the process for the acquisition of the fortress with the economic support of the Tuscany Region. This fact should solve the most important problem which in the past had stalled any initiatives, making the fortress a public cultural good.

This paper aims to show synthetically the first results of the interdisciplinary study carried out by the DESTeC aimed at the enhancement of the fortress and its territory. Starting from a careful territorial and historical analysis, the study focused on the identification of a mix of compatible functions, in order to maximize the use of the fortress in all the seasons. A feasibility study was also developed for verifying the economic sustainability of the whole project and identifying possible intervention phases. 


\section{Historical Analysis}

A campaign of archaeological excavations coordinated by Fabio Redi (Redi and Vanni 1987; 1988) in 1980s, testified the anthropization of the place since ancient times, confirmed by the discovery of scraps from flint processing in prehistoric times, pottery from the early Iron Age and other evidences attesting the human presence on the site since the first millennium BC.

The construction of some first fortified structures dates back to the Early Middle Ages, within the alternate vicissitudes that in the feudal period saw the cities of Lucca and Pisa contend for supremacy, with agreements or wars, suffering and/or favouring the influences of the respective bishops and of the imperial sovereignty.

An ancient document referring for the first time to a "Feudum Dominorum de Ripafracta" is stored in the State Archive of Lucca and is dated back to the tenth century ${ }^{1}$. A first castle should be referred to this period. The original structure was subsequently object of important fortification works starting from 1162 by the Republic of Pisa (Fig. 2). The construction of the central tower and the angular structures on the north and south of the fortified enclosure are in fact referable to this phase. The walls and towers located in the north-west and south-east corners were completed probably later. The work involved the construction of a further concentric perimeter of walls, for protecting the original small village of Ripafratta near the castle, and the strengthening of the line of defence towards Lucca with the construction, as we said, of the other five towers. A subsequent phase of modernization and fortification is documented in the years following 1314: the walls of the village on the side of the Vergario hill towards Lucca were completed, the fortress walls were raised and the current entrance on the same side of the hill, defended by a corridor, was opened.

At the middle of the fourteenth century, as represented by an illustration in Le Croniche $d i$ Giovanni Sercambi, lucchese (Bongi, 1892) the fortress had its perimetral walls completed and three high inner towers.

The last phase of construction refers to the years after 1509 , following the definitive conquest of Pisa by the Florentine Government. Giuliano da Sangallo was entrusted with the works, although these were supervised by his brother Antonio the Elder. The sixteenth century interventions tried to update the defensive systems of the fortress to the introduction of firearms in the siege tactics: the inner towers were cut to the height of the walls, the walls were reinforced with scarps at the base, two new ravelins with different levels of entreasures were built on the opposite sides of the entrance corridor.
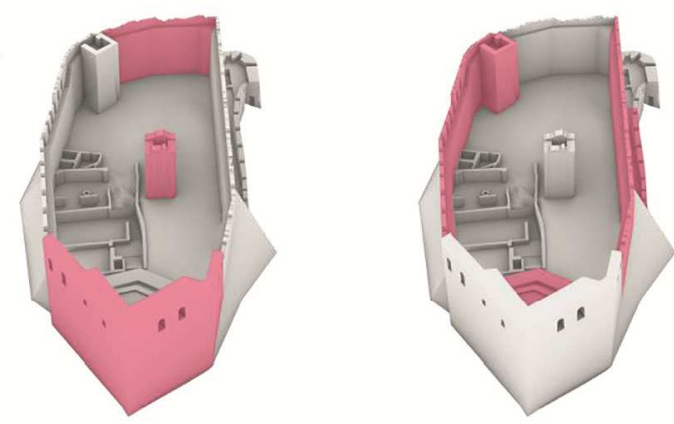

PHASE 2

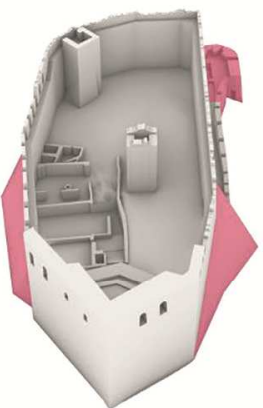

PHASE 3

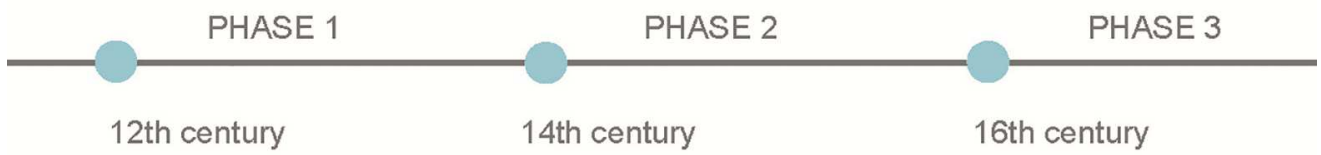

Fig. 2. Stratifications in the Fortress of Ripafratta. 
A century after these events, the fortress lost his military importance. As early as 1607 the fortress was in a state of neglect. In 1628 it was allocated for cultivation as orchard and vineyard. In 1678 the use passed to the grower of the Grand Ducal Estate of Collesalvetti, who after a few months gave it to the current owners, the noble Roncioni family.

\section{Research Methods}

The research was based on the results of a historical analysis of bibliographic sources. Among these, the results of the archaeological studies carried out by Fabio Redi (Redi, Vanni, 1987; 1988) was particularly useful for understanding the stratifications of the fortress. Other sources, such as Repetti (1846), Gentile (1905), Tolaini (1979) and other publications by Redi (Redi, 1990; Redi and Tangheroni, 1990; Redi, 2004), allow to contextualize the fortress and its stratifications within the broader historical framework of events related to the Pisan and Lucca territories during the feudal and republican period.

Furthermore, a careful urban analysis was developed, in a first phase limited to the Ripafratta area, with reference to the UTOE 2 (Homogeneous Elementary Territorial Unit) of the Structural Plan of the Municipality of San Giuliano Terme. $^{2}$

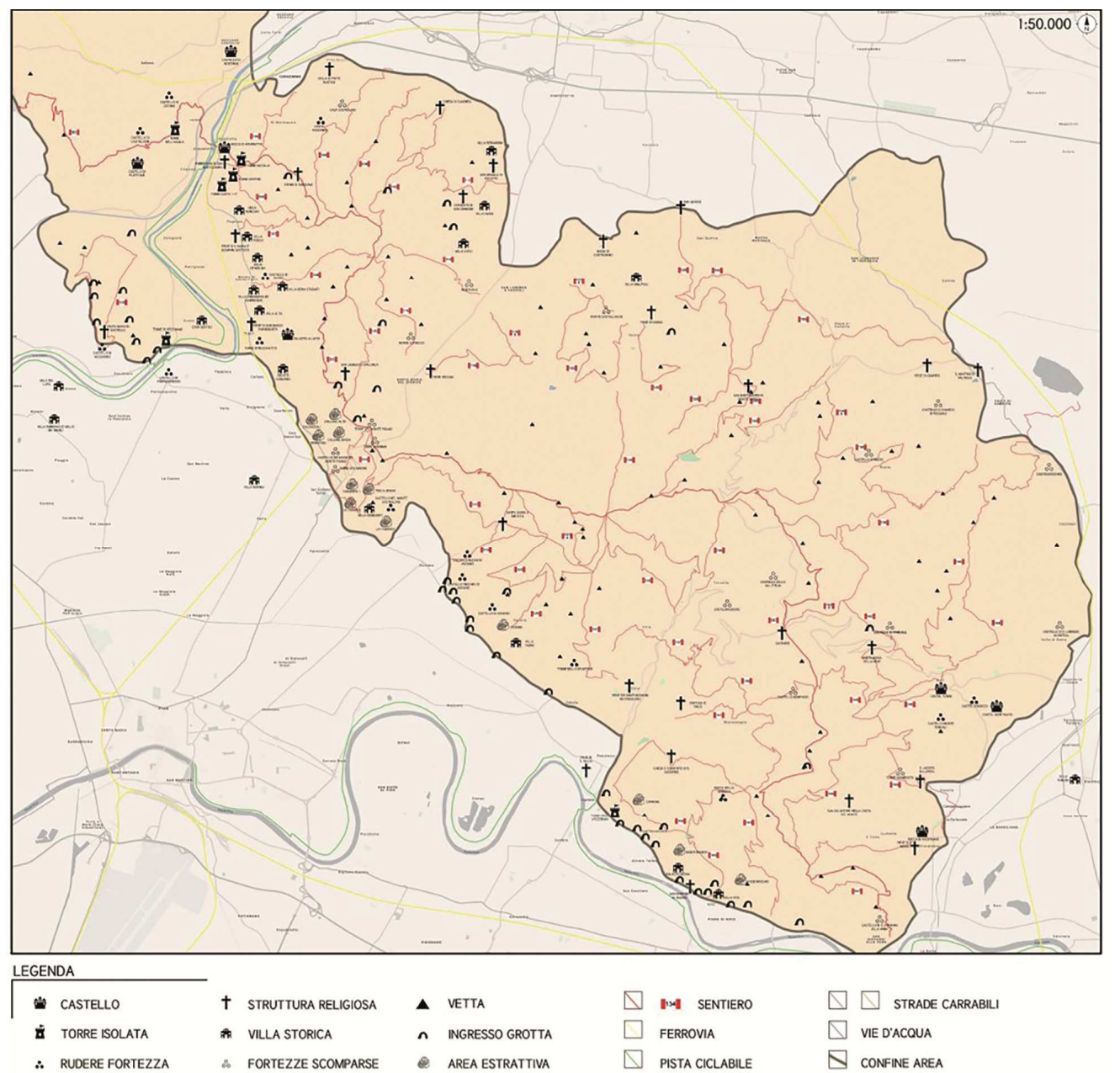

Fig. 3. Map of the whole Monte Pisano historical architectural system. 
Specifically, the analysis of transport infrastructures has shown how Ripafratta can be reached by all the means of transport -motor vehicles, train- and how it is connected to the cycle paths along the river Serchio and to the Tuscan hiking network. In addition to the Structural Plan of San Giuliano Terme, the analysis took in consideration the Territorial Plan of the Tuscany Region and the Serchio River Basin Plan.

In this first phase of analysis, it was also useful to meet and talk with the local community and the cultural and social associations that work for the development of the territory.

This analysis at a micro-territorial scale showed some potentialities of the area and the fortress, such as: the uniqueness of the monumental complex in the wider context of the Tuscan territory; the vocation of the whole area to the practice of outdoor sports and naturalistic activities; a great potential -in terms of cultural and touristic appeal- for the fortress if connected to the system of other fortifications of the territory and to the cultural and environmental ecosystem of the Monte Pisano and the Serchio River; the presence, in the village of Ripafratta, of many unused spaces for the development of commercial activities and the presence of several rooms and apartments available for rent on online circuits, which could be improved and systematized.

The analysis highlighted some criticisms also: first, the great amount of investments required for the acquisition and restoration of the fortress and the naturalistic requalification of its context; the necessity to improve the whole accessibility of the area; the needs of new parking areas, for decongesting the public spaces of the village and improving its urban quality; the quite total absence in the village of caterings; the fact that the fortress is still little known at regional and national level.

Following these first results, the analysis was therefore extended to the wider territorial context of the Monte Pisano, to which the fortress belongs. The macro system of the Monte Pisano presents many interesting sub-systems (Fig. 3): military and religious architectures, historical villas, historical quarries, as well as a series of other landscape, naturalistic and anthropic pecu- liarities scattered throughout the area, that can constitute an extremely virtuous system for the growth of the territory from the socio-economic point of view.

The urban and territorial analysis was followed by the analysis of project proposals developed for the fortress in the past; in particular, the feasibility study carried out by ASK Bocconi in 2015, the revision and integration of the study developed by the Association, as well as some master degree theses.

The Ask Bocconi proposal ${ }^{3}$ identified some functional guidelines for new activities to be planned in the fortress -eco-museum, multifunctional park, thematic park- on which all the economic considerations have been based. The definition of the capture rate was followed by the preparation of a business plan with the prevision of costs and revenues for the management of the new activities. In all the three proposed scenarios -prudential, average and optimistic- the study highlighted a significant cost-revenue deficit. The proposal drawn up by the Association ${ }^{4}$, based on the same approach set by Ask, defined three scenarios for a multifunctional park, of which only the prudential one generates deficits.

For the purposes of our study, it was necessary to develop an analysis of some reference benchmarks, chosen as virtuous example of enhancement and management of ancient fortresses and castles, such as: two touristic network of fortresses -the Apulian Federician Castles and the castles network in Trentino-; three Italian fortresses -the Canossa Castle, the Malaspina Castle in Fosdinovo, and the Castle of Vignola-; two additional foreign fortresses -the Dunnottar Castle in Scotland and the Castle of Cashel in Ireland-. All these benchmarks demonstrate that reusing historical fortified structures could generate benefits, for their territory, also in terms of economical self-maintenance.

\section{The project proposal}

The project proposal aims to define a sustainable scenario for the enhancement of the fortress and its territorial context ${ }^{5}$. The proposal provides three levels of intervention: general, inside the walls, outside the walls. 
The level of general interventions could be divided in primary and secondary. The primary ones include: the securing works for unstable parts of the fortress; the conservative restoration works of the fortress; the recovery of the Vergario Hill; the improvement of the accessibility to the site; the mitigation of the hydrogeological risk of the site. The secondary objectives include: the recovery of the urban spaces in the village of Ripafratta; interventions for supporting the development of activities for touristic purposes in the village; networking activities for enhancing all the sub-systems of the Monte Pisano under a unique brand; the improvement of the existing naturalistic and sport activities in the area.

The interventions inside the walls mainly concern new functions to be placed in the fortress, identified thanks to the analyses carried out in the study. The first level of functions is primarily educational and cultural, with the creation of activities for schools, such as historical reenactments and educational workshops on historical, archaeological and scientific topics. The second concerns touristic activities, such as: guided visits to the fortress and its environments, to the archaeological area, along its sheltered walkways and to a new museal area; but also concerns the organization of historical reenactments for touristic purposes. The third level of functions includes different types of events such as concerts, performances, conferences, exhibitions, fairs, private parties- to be organized renting some parts of the fortress for limited periods.

These three levels of functions will be developed inside the fortress, in open-air spaces, such as a new theatre, or in a new building, to be realized with light and removable structures and inner flexible spaces (Fig. 4). All these interventions will be developed in the next future. Currently, the project has verified the possibility to create an open-air theatre of about 200 seats and a new building for touristic services with a covered surface of $350 \mathrm{~m}^{2}$ approximately.

In order to improve the overall touristic offer of the area, some ideas have been proposed for the area outside the walls of the fortress, on the Ver- gario hill and in the village of Ripafratta (Fig. 5), such as: the realization of a diffused hotel, the creation of educational farms in the area and a market for local products in the village, the recovery of the historic terraces of the Vergario hill for camping, the realization of a new sportsadventure park in the area between the fortress and the towers Niccolai and Centino.
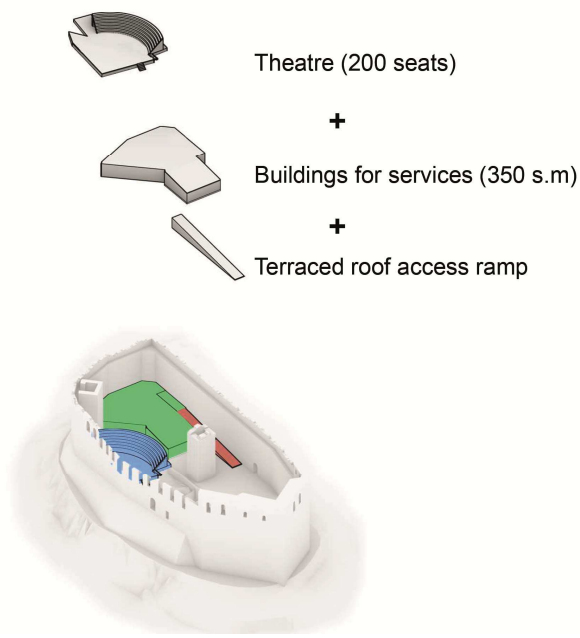

Fig. 4. Graphic diagram of the new functions to be placed in the fortress.

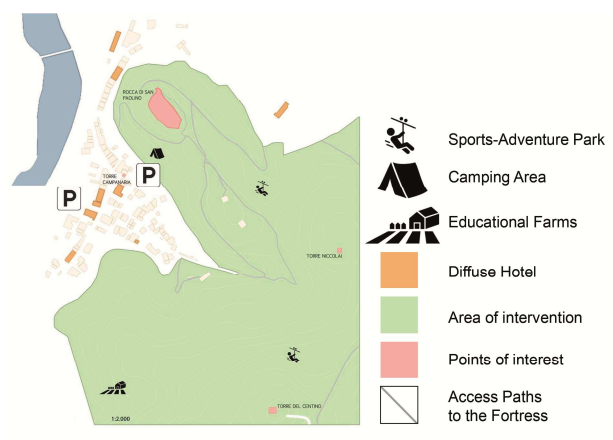

Fig. 5. Graphic scheme of new activities for the area outside the fortress.

Following the identification of the new functions and the development of the preliminary proposal, a business plan was developed, along the same lines as that by ASK Bocconi and implementing it thanks to the benchmarks analysis and in the light of the study results. 
The business plan shows three possible scenarios -prudential, average, optimistic- in which it's possible to hypothesize the achievement of a balanced budget. Costs are related to the day-today management (personnel, insurance, utilities, ordinary maintenance), while revenues include ticketing, rents for external events and merchandising.

In the study, a calculation of the costs for the overall recovery of the fortress and its neighbouring has been developed. The calculation includes costs for the acquisition of the fortress, for the development of preliminary surveys and studies, for restoration and recovery works, for the realization of structures inside the fortress, and for the mitigation of the hydrological risk and the overall redevelopment of the external area near the fortress.

In order to open the fortress to the public as soon as possible, even if partially and with limited activities -as to make the "Rocca di Ripafratta" system profitable before the end of such a huge amount of works and during the same- a program of interventions have been developed, di- viding the area in lots and hypothesizing 9 phases of intervention, with costs and partial revenues calculated for each of them (Fig. 6).

\section{Conclusions}

This study represents the first step of a long process aimed at the enhancement of the fortress and its territory.

Once the fortress has been acquired as a public good, it will be possible to seek financing for the development of the project, both for preliminary analysis and for more specific activities related to restoration works. We hope, therefore, to show the results of further steps of the research in the next future.

\section{Notes}

${ }^{1}$ Archivio Arcivescovile di Lucca +E. n. 75, in Gentile, 1905, p. 9, n. 2.

2 The Structural Plan of the municipality of S. Giuliano, dating 2017.

${ }^{3}$ ASK Bocconi, Rocca di S. Paolino in Ripafratta, Studio di funzionalizzazione della Rocca di
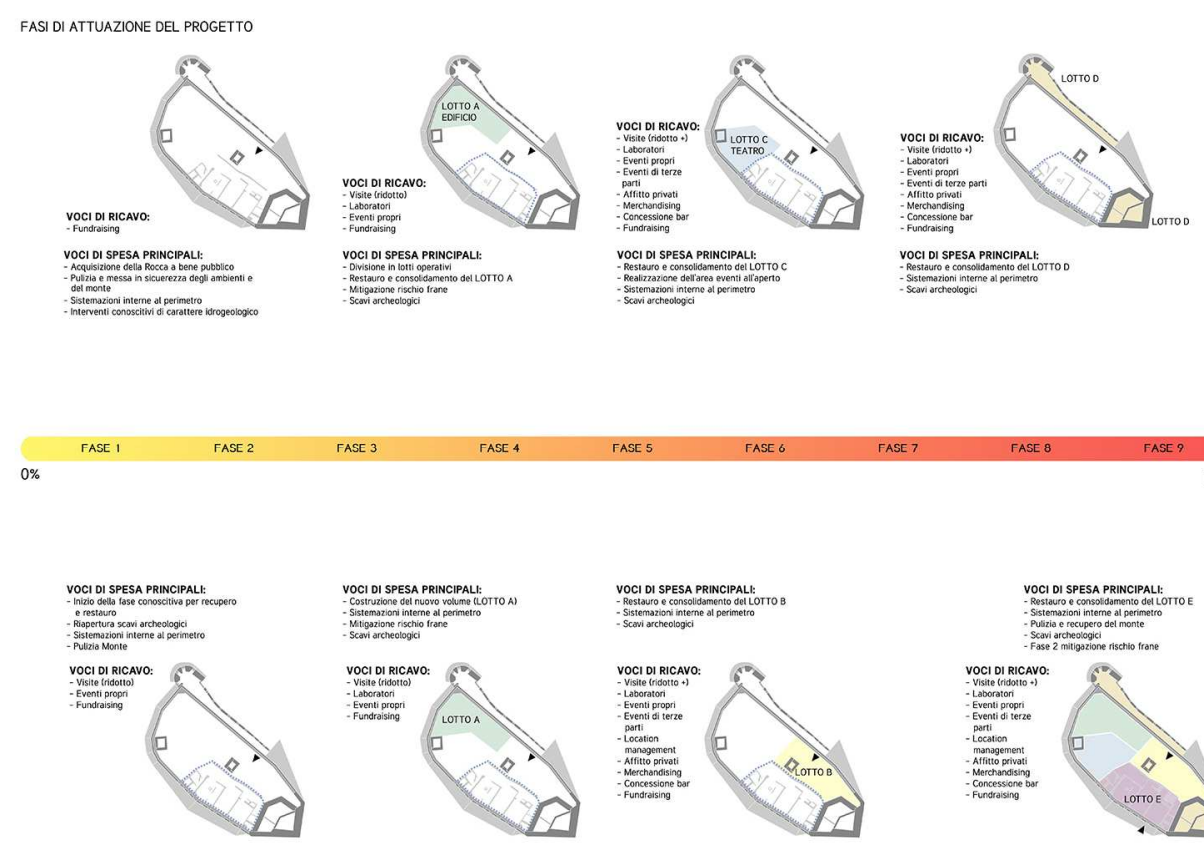

$$
\text { TASE } 3
$$
TASE 4 TASE 5 TASE 6 TASE 7

Fig. 6. Phases of interventions of the restorian and recovery works. 
San Paolino in Ripafratta a seguito di opere di restauro, Università Luigi Bocconi, Milano, 2015.

${ }^{4}$ Salviamo la Rocca APS, Per un parco archeoambientale a Ripafratta, 2015.
${ }^{5}$ The project is still ongoing, and the results will be presented to the public early next year. Therefore, any explicit references to costs and revenues are prudentially not expressed.

\section{Bibliography}

Bongi, S. (1892). Le Croniche di Giovanni Sercambi, lucchese pubblicate sui manoscritti originali a cura di Salvatore Bongi, Tipografia Giusti Ed., Lucca.

Gentile, M.L. (1905). "Sulla consorteria feudale dei nobili di Ripafratta", in Giornale storico e letterario della Liguria, Tipografia della Gioventù Ed., Genova, vol. 6, pp. 5-66.

Redi, F. (1990). Medioevo vissuto, Primi dati sulla cultura materiale del castello di Ripafratta, i reperti dello scavo, Giardini Ed., Pisa.

Redi, F. (2004). La frontiera lucchese nel Medioevo torri, castelli, strutture difensive e insediamenti fra strategie di potere e controllo del territorio nei secoli XII e XIV, Silvana Ed., Cinisello Balsamo.

Redi, F.; Tangheroni, M. (1990). San Giuliano Terme: la storia, il territorio, Giardini Ed., Pisa.

Redi, F.; Vanni, F.M. (1987). "Ripafratta (Pisa). Rapporto preliminare, 1983-1986”, Archeologia Medievale. Cultura Materiale. Insediamenti. Territorio, XIV, pp. 289-318.

Redi, F.; Vanni, F.M. (1988). "Ripafratta (Pisa) 2", Archeologia Medievale. Cultura Materiale. Insediamenti. Territorio, XV, pp. 417-438.

Repetti, E. (1846). Dizionario geografico fisico storico della Toscana, coi Tipi Allegrini e Mazzoni, vol. IV, pp. 767771.

Tolaini, E. (1979). Forma Pisarum: storia urbanistica della città di Pisa, Nistri Lischi Ed., Pisa. 